\title{
Anti-Biofilm of Various Histatin 5 Concentrations Against_Streptococcus Mutans From Salivary Isolate
}

\author{
Dharli Syafriza ${ }^{1}$, Heriandi Sutadi ${ }^{2}$, Ameta Primasari $^{3}$, Yahwardiyah Siregar ${ }^{4}$ \\ ${ }^{1}$ Doctoral Programme Student, Faculty of Dentistry Universitas Sumatera Utara, Jl. Alumni No. 2 Kampus USU, \\ Medan, Indonesia \\ ${ }^{2}$ Department of Pediatric Dentistry, Faculty of DentistryUniversitas Indonesia,Jl. Salemba Raya, Jakarta \\ Indonesia \\ ${ }^{3}$ Department of Oral Biology, Faculty of Dentistry Universitas Sumatera Utara,Jl. Alumni No. 2 Kampus USU, \\ Medan, Indonesia \\ ${ }^{4}$ Department of Biochemistry, Faculty of Medicine Universitas Sumatera Utara,Jl. Dr. Mansyur No. 5 Kampus \\ USU, Medan, 20155 Indonesia \\ *Correspondence author email : dharli.pedo@gmail.com
}

\begin{abstract}
Streptococcus mutan is the main agent infection of dental caries. Histatin 5 has been reported as the antimicrobial agents also to prevent the formation of biofilms of oral pathogen biofilm, like $S$. mutans involve in dental caries pathogenesis. This study aims to determine the effect of anti-biofilm of histatin 5 on the $S$. mutans salivary isolate. Identify of $S$. mutans used to the selective medium (TYS20B) also confirmed by Gram staining and the antibiofilm $S$. mutans was assayed by crystal violet $0.1 \% \mu 1 / \mathrm{U}$. Meanwhile, the value of anti-biofilm analyzed by Enzyme-linked immunosorbent assay (ELISA) reader, based on the optical density in wavelength $575 \mathrm{~nm}$. The potency of the histatin 5 to anti-biofilm of $S$. mutans salivary isolate among the concentration 25 and $50 \mathrm{ppm}$ higher than the positive control, but in 12.5 and $6.25 \mathrm{ppm}$ are lower than the positive control. Among concentration as the anti-biofilm of $S$. mutans were significant $(\mathrm{p}<0.05)$. Histatin 5 has potential as the anti-biofilm of $S$. mutans and the concentration of 50 and $25 \mathrm{ppm}$ can be recommended for the simulation of anti-S. mutans.
\end{abstract}

Keywords: biofilm formation, Streptococcus mutans, histatin 5, crystal violet 


\section{INTRODUCTION}

Data from Baseline Health Research (Riskesdas) Ministry of Health Republic of Indonesia 2017 shows that from 2007 to 2010 the prevalence of active caries in Indonesia increased from $43.4 \%$ to $53.2 \%$ or equal to 93 million people [1]. This data shows that dental caries still a major problem in oral health in Indonesia. Caries is a multifactorial disease and cariogenic bacterium named Streptococcus mutans is the main agent infection. This organism subsequently able to produce organic acids and can survive in an acidic environment [2]. The polysaccharides secreted by Streptococcus mutans cause these bacteria able to adhere to tooth surfaces and subsequently produce carbohydrates for metabolism if there were no more food sources [3].

Biofilms, also called plaques, provide the most suitable areas for Streptococcus mutans to adhere, colonize and multiply. An increase number of Streptococcus mutans has an adverse effect to email because the acid produced by Streptococcus mutans caused demineralization of email. Therefore, another way to inhibit cariogenic bacteria growth is by preventing the attachment of cariogenic bacteria to the tooth surface through bioflim. Various anti-bacterial agents to inhibit the formation of biofilms in Streptococcus mutans have been widely studied and utilized, one of which is histatin 5 [4].

Histatin 5 belongs to the histidine-rich peptide family (histidine-rich peptide), the largest antimicrobial peptide in saliva derived from parotid and submandibular salivary gland cells. Among the 12 main peptides, which are present in saliva are histatin1,3 , and 5 about $85 \%$ of the total histatin in saliva [4,5]. Histatin peptides have biological activities protecting the oral cavity from infectious diseases including caries $[4,6]$.

Antimicrobial of histatin mechanism in killing microorganisms is through intracellular target killing model, by inhibiting enzyme activity, inhibiting DNA and RNA synthesis, or through interaction with various intracellular targets with direct penetration and endocytosis [7]. MacKay et al tested growth inhibition and survival of $S$. mutans cells, concluding that histidine-rich peptides isolated from human parotid salivary glands are bacteriostatic and bactericidal against $S$. mutans. This shows the antibacterial role of histidine-rich peptides in environments in normal $\mathrm{pH}$ [8].

One of the strongest anti-microbial activities is histatin 5. Histatin 5 was derived from histatin 3 due to post-translational modification, and has a biological role in the non-immune defense system [9]. Statistical analysis showed a significant increase in the concentration of histatin 5 in the saliva of children with Early Childhood Caries (ECC) compared to the control group and the correlation with caries progression.

This shows that changes in the concentration of histatin 5 during the process of caries development may be an important value in the development of caries [10]. Other studies have concluded that histatin 5 can inhibit the growth of $S$. mutans [11]. Until now, the effect of anti-biofilm histatin 5 on caries-causing bacteria, Streptococcus mutans, is unknown. Based on the foregoing, this study aims to determine the antibiofilm histatin 5 effect on caries-causing bacteria, Streptococcus mutans.

\section{MATERIAL AND METHODS}

The ethical clearence of this research was approved by Medical Faculty, Universitas Sumatera Utara, No. 41/TGL/KEPK FK USU-RSUP HAM/2018). The $S$. mutans was isolated from saliva of children with Early Childhood Caries (ECC) and then cultured in medium selective of TYS20B. Streptococcus mutans salivary isolate were identified by gram staining that confirmed by microscopic. Streptococcus mutans target (1-2 colonies) then transferred to $30 \mathrm{ml}$ of TYS20B liquid media, incubated at $37^{\circ} \mathrm{C}$ for 24 hours while remaining agitated (shaking) at $120 \mathrm{rpm}$. After 24 hours, the bacteria in the liquid media were taken using a micropipette to dilute up to $10^{4} \mathrm{CFU} / \mathrm{ml}$, homogenized by shaking, and put $200 \mu \mathrm{l}$ into the well.

Human histatin 5 (AnaSpec, Inc. Fremont, USA) of $1 \mathrm{mg}$ was dissolved in Nuclease Free Water (Sigma-Aldrich Co., St. Louis, USA) until reach concentrations of $50,25,12.5$ and $6.25 \mathrm{ppm}$ [11]. Total of $50 \mu \mathrm{l}$ histatin 5 was put into the wells. As a positive control, $0.2 \%$ Chlorhexidine solution was used and a negative control was a bacterial liquid media (TYS20B). After 48 hours incubation, the bacteria in each well were removed, wash with $275 \mu 1$ of sterile aquadest, and repeated for 3 times. Well then fixed heat in the oven at $70^{\circ} \mathrm{C}$ for 20 minutes. Add 250 $\mu \mathrm{l}$ of sterile violet crystals (concentration of $0.1 \%$ $\mu \mathrm{l} / \mathrm{U}$ ) and let it soak for 1 minute, then the violet crystals were removed and well washed for 3 times with $275 \mu \mathrm{l}$ of $95 \%$ ethanol. At the last washed, $95 \%$ ethanol was allowed to stand in well for 2 minutes before disposal. The absorbance measured by ELISA reader in $575 \mathrm{~nm}$ wavelenght. The formula of anti biofilm OD was adopted by Odeyami [12] and Kim [13], where OD Biofilm $=$ ODa-ODnc $(\mathrm{ODa}=\mathrm{OD}$ cell $S$. mutans; ODnc= negative control). The indicator of 
antibiofilm OD refer to these theory, $\geq 0,41$ (strong); 0,31-0,4 (moderate); 0,2-0,3 (weak); and < 0,15 (no biofilm).

\section{RESULT}

Optical Density (OD) of Histatin5 at all concentrations shows the potential of antibiofilms.The OD histatin group of $50 \mathrm{ppm}$ with a mean yield of $0.11 \pm 0.00$ showed the highest percentage of anti-biofilms (28\%) and the $6.25 \mathrm{ppm}$ group showed the lowest percentage of anti-biofilms $(22 \%)$. The results of OD showed that histatin 5 in the $6.25 \mathrm{ppm}$ group had the effect of inhibiting the formation of $S$. mutans biofilms in vitro with an average value of $0.32 \pm 0.10$. The higher concentration of histatin 5 results the smaller optical density value of bacterial biofilms. It showed the number of microorganisms which accumulates less and less in the structure of biofilms. It can be concluded that histatin 5 was an concentration dependent antimicrobial agent in saliva which has potential effects as an anti-caries agent and has an anti-biofilm effect against $S$. mutans. The results can be seen in the following Fig. 1

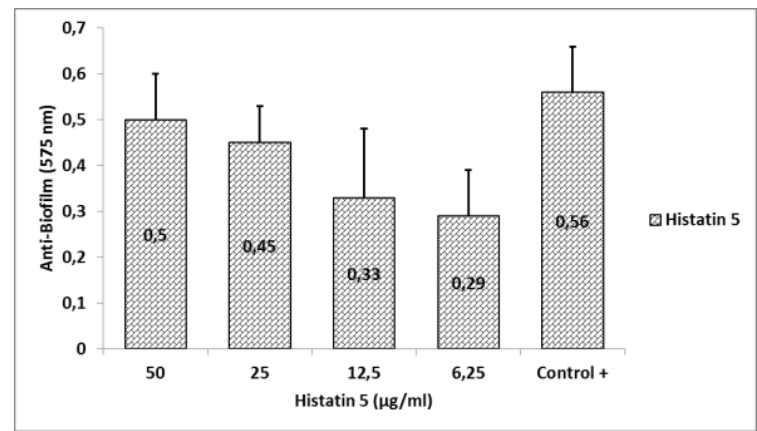

Figure 1.Optical density anti-biofilm of histatin 5 on the $S$. mutans salivary isolate. All of the concentrations have anti-biofilm, in 50 and $25 \mathrm{ppm}$ has a strong effect $(\geq 0.41)$ and 12.5 to 6.25 were moderate effect $(0.31-0.4)$. The positive control (Chlorhexidine $0.2 \%$ )was higher effect than histatin 5 of all concentrations. Bar (OD anti-biofilm) andbar error (standar deviation).

This study proved that positive control has the ability to $S$. mutans biofilms in a weak category. The percentage of histatin 5 compared to the OD value of the positive control showed that the highest value at $6.25 \mathrm{ppm}$ was $41 \%$ and the lowest value that found in the 50 ppm group was $9 \%$. The results of histatin 5 OD on positive control can be seen in the following Table 2 and the comparison interpretation in Fig.2:

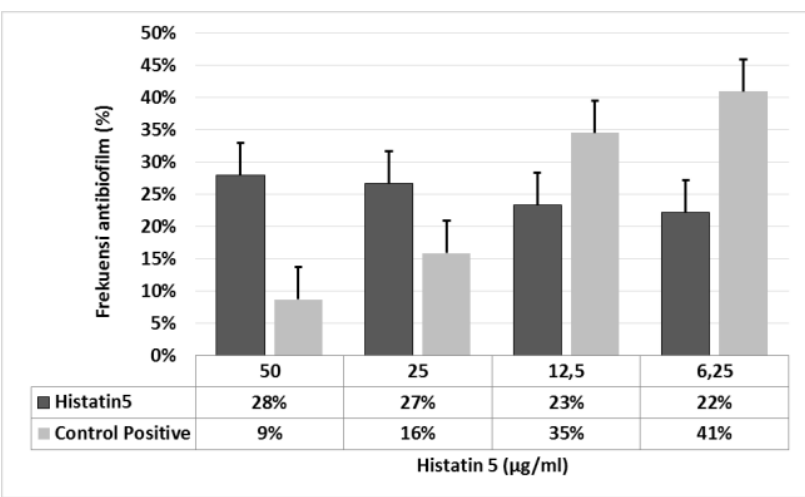

Figure 2. Frequency of histatin 5 anti-biofilm on the $S$. mutan salivary isolate. The concentration of 50 and $25 \mathrm{ppm}$ has higher ability anti-biofilm than the positive control. Bar (frequency of anti-biofilm) and

Bar error (Standard deviation of percentage).

Table 1.One Way Anova analysis of anti-biofilm of Histatin 5 on the $S$. mutans salivary isolate

\begin{tabular}{|c|c|c|c|c|c|c|c|}
\hline \multirow[b]{2}{*}{$\begin{array}{l}\text { Histatin } 5 \\
\text { Concentrat } \\
\text { ion }\end{array}$} & \multicolumn{5}{|c|}{ Statistical descriptive } & \multicolumn{2}{|c|}{$\begin{array}{c}\text { One Way } \\
\text { Anova }\end{array}$} \\
\hline & $\mathrm{n}$ & $\begin{array}{c}\mathrm{Me} \\
\text { an }\end{array}$ & $\begin{array}{l}\text { M } \\
\text { ax }\end{array}$ & $\begin{array}{l}\mathrm{M} \\
\text { in }\end{array}$ & $\begin{array}{c}\text { SD } \\
\mathrm{V}\end{array}$ & $\begin{array}{l}\text { Betw } \\
\text { een } \\
\text { Grou } \\
\text { ps }\end{array}$ & $\begin{array}{l}\text { Wit } \\
\text { hin } \\
\text { Gro } \\
\text { ups }\end{array}$ \\
\hline 50 & 3 & $\begin{array}{c}0,1 \\
1\end{array}$ & $\begin{array}{l}0, \\
11\end{array}$ & $\begin{array}{l}0, \\
11\end{array}$ & 0,1 & & \\
\hline 25 & 3 & $\begin{array}{c}0,1 \\
6\end{array}$ & $\begin{array}{l}0 \\
24\end{array}$ & $\begin{array}{l}0, \\
09\end{array}$ & $\begin{array}{c}0,0 \\
8\end{array}$ & $\mathrm{p}<0,0$ & $\mathrm{p}>0$, \\
\hline 12,5 & 3 & $\begin{array}{c}0,2 \\
8\end{array}$ & $\begin{array}{l}0, \\
45\end{array}$ & $\begin{array}{l}0, \\
17\end{array}$ & $\begin{array}{c}0,1 \\
5\end{array}$ & $\begin{array}{c}5 \\
(0,00\end{array}$ & $\begin{array}{c}05 \\
(0,7\end{array}$ \\
\hline 6,25 & 3 & $\begin{array}{c}0,3 \\
2\end{array}$ & $\begin{array}{l}0 \\
4\end{array}$ & $\begin{array}{l}0, \\
21\end{array}$ & 0,1 & 3) & 51) \\
\hline $\begin{array}{c}\text { Control + } \\
(\mathrm{CHX})\end{array}$ & 3 & $\begin{array}{c}0,0 \\
5\end{array}$ & $\begin{array}{c}0, \\
05\end{array}$ & $\begin{array}{l}0, \\
05\end{array}$ & 0,1 & & \\
\hline
\end{tabular}

Table 1 showed the between groupsstatistical analyzed by one way ANOVA test obtained $\mathrm{p}$ value $<0.05$.

\section{DISCUSSION}

As it was known, the cariogenic character of $S$. mutans were the ability to form biofilms in the oral cavity which have an important role in the occurrence of caries and its formation would produce interactions between species of the same bacteria and other bacteria. The anti-bacterial ability of histatin 5 on the growth of $S$. mutans in this study was carried out by the microtiter plate method. The deep purple wall of the wells indicates the formation of $S$. mutans biofilms. Formation in the well wall was related to the non-motile nature of $S$. mutans, whereas in bacteria 
with a lot of color movement it would be centered on the upper surface. The formation of purple attached to the wall of the well was basically following the principle of Gram staining. Gram-positive bacteria had very thick peptidoglycan cell walls, so that when bacteria were stained with primary coloring agents (violet crystals), gram-positive bacteria would absorb dyes. When dehydrated with alcohol, the cell wall pores would closed and violet crystals remain in the cell so that the cells turn purple.

These anti-biofilm results accordance with several studies that have been conducted. Krzyciak et al mentioned the antibacterial activity of histatin 5 peptide against $S$. mutans at concentration of $54.4 \mu \mathrm{g} / \mathrm{ml}$ after 72 hours of incubation. A low average absorbance value confirms the number of bacteria that accumulates in the biofilm structure were low [11]. In addition, the effect of histatin 5 on biofilm formation also investigated by Helmerhorst et al on 7 species of bacteria commonly observed in the oral cavity including S.mutans. They concluded, S. mutans accumulated in biofilms showed susceptibility to histatin 5 at a concentration of $100 \mu \mathrm{g} / \mathrm{ml}$ [14].

Huo et al. analyzed the effect of histatin 5 on $S$. mutans growth using the P113 peptide (the shortest fragment of the histatin protein consist 12 amino acids) with the Electrophoretic Mobility Shift Assay (EMSA) method. The mean of Minimum Inhibitory Concentrations (MIC) of this peptide for S. mutans UA 159 strains was $27.29 \mu \mathrm{M}$ which seen after 10 hours incubation. Furthermore, the activity of these peptides at these concentrations was proportional to the activity of $1.60 \mu \mathrm{M}$ Chlorhexidine which showed the same growth inhibition after 4 hours, incicated that histatin 5 can induce intracellular activity changes of microorganisms without disturbing membrane integrity [15].

In our study shows that histatin 5 has potential as an anti-biofolm agent at $25 \mathrm{ppm}$ and $50 \mathrm{ppm}$. These concentrations has strongly anti-biofilm of $S$. mutans and consistent with research that states the mechanism of action of salivary peptides in each individual varies greatly depending on the concentration of the peptide. As known, during the process of infection, antimicrobial peptides have several simultaneous mechanisms action, combining the process of destabilizing cell membranes and inhibiting intracellular targets [16]. Antimicrobial mechanisms can affect bacterial cell targets and the physical properties of the membranes that interact were known to be influenced by concentration. This was reinforced by the results of the comparison of OD histatin 5 with positive control at all concentrations based on the results of the Kruskal Wallis test which showed no significant differences $(\mathrm{p}>0.05)$. Histatin 5 at concentrations $12.5 \mathrm{ppm}$ and $25 \mathrm{ppm}$ was also potential as anti-biofilm but in weak category. Correlation test which was conducted to determine the relationship between the concentration of histatin 5 on OD bacterial biofilms shows that there was a significant correlation with the direction of a positive correlation and has a very strong power $(p<0.05)$. The higher concentration of histatin 5 would results smaller OD value, which indicates that biofilm structure with lower bacterial accumulations.

\section{CONCLUSION}

The anti-biofilm histatin on $S$. mutans at concentrations 50 and $25 \mathrm{ppm}$ were recommended for the simulation of anti-S. mutans in the pathogenesis of dental caries.

\section{REFERENCES}

[1] Ministry of Health, Republic of Indonesia Baseline Health Research 2017. JakartaIndonesia

[2] Zussmana E, Yarin, A and Nagler R. Age and flow dependency of salivary viscoelasticity. $J$. Dent. Res, 86 (3), pp. 281-285, 2007

[3] McIntyre J. Dental root surface caries study. Aust Dent J. 45(4):290, Dec 2000

[4] Dodds MWJ, Johnson DA, Yeh CK. Health benefits of saliva: a review. J Dent. Mar; 33 223233. 2005

[5] Khurshid Z, Naseem M, Sheikh Z, Najeeb S, Shahab S, Zafar MS. Oral antimicrobial peptides: Types and role in the oral cavity. Saudi Pharm J.24 (5):515-524, 2016

[6] Seo MD, Won HS, Kim JH, Mishig-Ochir T, and Lee BJ. Antimicrobial peptides for therapeutic applications: a review. Molecules; 17, 12276-12286, 2012

[7] Mai S, Mauger MT, Li-na N, Barnes JB, Kao S, Jun-qi Ling, Tay FR. Review article: potential applications of antimicrobial peptides and their mimics in combating caries and pulpal infections. Acta Biomater 2016. http://dx.doi.org/10.1016/j.actbio.2016.11.026

[8] MacKay BJ, Pollock JJ, Iacono VJ, Baum BJ. Isolation of milligram quantities of a group of histidine-rich polypeptides from human parotid saliva. Infect Immun. Jun; 44(3):68894, $\quad 1984$

[9] Oppenheim FG, Xu T, Mc Millian FM, Levitz SM, Diamond RD, Offner GD, et.al. Histatins, a novel family of histidine-rich proteins in 
human parotid secretion. Isolation, characterization, primary structure, and fungi static effects on Candida albicans. J Biol Chem. 263:7472-7, 1988

[10] Jurczak A, Kościelniak D, Papież M, Vyhouskaya $\mathrm{P}$ and Krzyściak W. A study on $\beta$-defensin-2 and histatin-5 as a diagnostic marker of early childhood caries progression. Biol Res. 48:61, 2015

[11] KrzyściakW, Jurczak A, Piątkowski J, Kościelniak D, Gregorczyk-Maga I, Kołodziej I, Papiez M, Olczak-Kowalczyk D. Effect of histatin5 and lysozyme on the ability of Streptococcus mutans to form biofilms in in vitro conditions. Postepyhig meddosw (online). 69; 1056-1066, 2015

[12] Odeyani and Olumide A. Microtiter plate assay methods of classification of bacterial biofilm formation. Food Control, 73: 245-246, 2017
[13] Kim, Se-Hun, et al. Biofilm formation of Campylobacter strains isolated from raw chickens and its reduction with DNase I treatment. Food Control, 71: 94-100,2017

[14] Helmerhorst EJ, Hodgson RW, van't Hof;Veerman EC I, et al. The effects of histatin-derived basic antimicrobial peptides on oral biofilms. J Dent Res. 78, 6; Jun 1999

[15] Huo L, Zhang K, Ling J, Peng Z, Huang X, Liu $\mathrm{H}, \mathrm{Gu}$ L. Antimicrobial and DNA-binding activities of the peptide fragments of human lactoferrin and histatin 5 against Streptococcus mutans. Arch Oral Biol. 56(9):869-76, 2011

[16] Fernández-Presas AM, Torres YM, Gonzales RG, Torres AR, Fauser IB, Barrera HR, et al. Ultrastructural damage in Streptococcus mutans incubated with saliva and histatin 5 . Arch Oral Biol. 87:226-34, 2018 